\title{
Disarray in global governance and climate change chaos*
}

\author{
George Martine ${ }^{\star \star}$ \\ José Eustáquio Diniz Alves ${ }^{\star \star \star}$
}

\begin{abstract}
Scientists warn that human activity in the Anthropocene is causing the transgression of several planetary boundaries. The population/environment/development equation has become insoluble. This paper reviews the trajectory of climate change and discusses the shortcomings of ongoing efforts to address it. It analyzes the current crisis in global governance, fostered by widespread disenchantment with globalization, and reflects on the risks that the resulting political imbroglio presents for our environmental future. Global responses are ineffective due to crumbling multilaterism and the continuing promotion of unsustainable economic growth based on consumerism. Discontent with the consequences of globalization has destabilized national governance and, in the process, further corroded prospects for effective global governance in facing symbiotic social, political and environmental crises. Frustration with globalization is providing media populists a platform from which to attract voters with naive schemes that highlight climate change denial. Potential pathways and obstacles for multilateralism in efforts to resolve the current crisis are blurred. Blind faith in technology, negationism, and the pervasiveness of the consumer culture further hamper awareness raising. Unfortunately, voters, institutions and policies may only adjust when the intensification of climate disasters forces a sea change in outlook.
\end{abstract}

Keywords: Planetary boundaries. Governance crises. Growth ideology. Globalism versus populism. Alternative solutions.

\footnotetext{
* The authors wish to thank Gordon McGranahan, Ralph Hakkert, Peter Bakuzis, Rene Vossenaar, Jorge Rodriguez and Roberto do Carmo as well as an anonymous referee from REBEP for their helpful comments on previous versions. The contents of this paper are the sole responsibility of the authors.

** Independent consultant, Brasília-DF, Brazil (georgermartine@yahoo.com; https://orcid.org/0000-0001-5876-2540).

*** Escola Nacional de Ciências Estatísticas (Ence), Instituto Brasileiro de Geografia e Estatísticas (IBGE), Rio de Janeiro-RJ, Brazil (jed_alves@yahoo.com.br; https://orcid.org/0000-0001-6095-9668).
} 


\section{Introduction}

The 1990s presaged a bright new phase in global governance, with the fall of the Berlin Wall serving as backdrop for the dawn of a new global order. The United Nations spearheaded a quest for international consensus through a series of conferences on vital issues ranging from Human Rights to sustainability. Meanwhile, the economic tenets inspired by the Washington Consensus promised widespread economic growth and important social benefits for the world's population. A quarter century later, prospects for prosperity, democracy and global harmony have dimmed drastically. The long-lasting debate involving population, development and environment appears to have become an insoluble equation. Economic growth in a globalized market framework was achieved at the cost of infringing planetary limits, aggravating conflict, expanding inequality within countries and creating a global plutocracy with unprecedented wealth and power.

Such consequences have contributed to the destabilization of governance at both national and global levels, and - paradoxically - to the incipient demise of the current globalization cycle itself. International interdependence has never been greater, yet global governance is at a low ebb. World solidarity is overwhelmed by symbiotic social, political and environmental crises. Negative reactions to this situation from poorer countries were predictable, but the force of protectionism that gushed from more advanced economies, in reaction to globalism, constitutes the greatest threat to human welfare. Such geopolitical developments further accentuate deficiencies in the outdated structure of multilateralism and magnify the challenges for global governance.

This paper deals specifically with governance on climate change, the most critical global issue of our time, as persuasively confirmed by a plethora of scientists and scientific organizations, as well as by the UN and multilateral financial agencies. ${ }^{1}$ The paper reviews the trajectory of climate change and the limitations of ongoing efforts to deal with it, discusses the environmental risks stemming from global governance disruptions plus disenchantment with globalization and, finally, considers potential pathways and obstacles to the resolution of the current quandary.

\section{Development and climate change}

The unprecedented expansion of economic growth in recent decades has greatly boosted the availability of goods and services for the globe's inhabitants. However, as amply documented, and expressed in Figure 1, this success has been achieved at the cost of depleting both resources and sink capacity (Cf., for instance, DALY, 1996, 2014).

Unsustainability has been growing continuously, as both the number of people and income per capita increased. This has led to the infringement of crucial planetary boundaries. Numerous studies, such as those from the University of Stockholm (ROCKSTROM et al.,

\footnotetext{
$\overline{1}$ For an impressive but still partial listing of concerned scientists and institutions, cf. Marques (2019).
} 
2009; STEFFEN et al., 2015, 2018), show that such transgressions could generate a much less hospitable state for the planet and increase the risks for world population, especially the poor, while frustrating efforts to reduce poverty and leading to the deterioration of human well-being.

FIGURE 1

Global GNP and global ecological deficit - 1971-2016

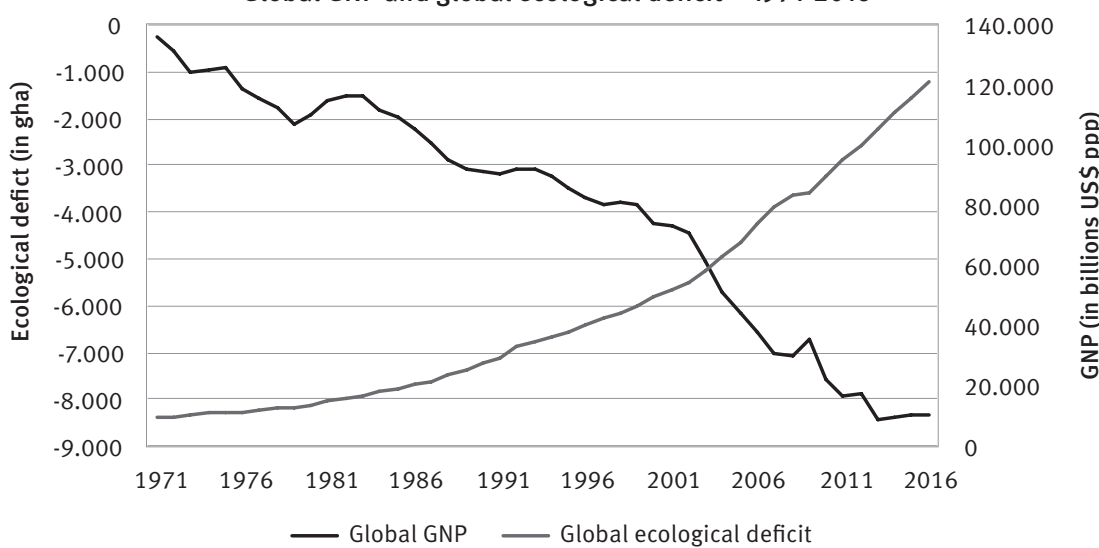

Source: International Monetary Fund (IMF), World Economic Outlook (WEO), April 2018 (http://www.imf.org/external/datamapper/ datasets/WEO); Global Footprint Network (http://data.footprintnetwork.org/\#/exploreData).

Further violation of two "core" planetary boundaries - climate change and biodiversity integrity - would be particularly catastrophic and could lead to the collapse of civilization as we know it (ROCKSTROM et al., 2009; STEFFEN et al., 2015, 2018; BARNOSKY et al. 2012; GRIGGS et al., 2013). Even studies published under the Trump administration warn that self-reinforcing feedbacks within the climate system have the potential to create state shifts (USGCRP, 2017, ch.15). Such feedbacks could trigger a domino-like cascade of events that would prevent stabilization of the global climate at intermediate temperature rises and cause continued warming on a "Hothouse Earth" pathway even if human emissions were to be reduced (STEFFEN et al., 2018).

The consequences of staying the present course are disastrous. The inherent volatility of the weather provides leeway for misinterpretation by negationists of the origins and dimensions of ongoing climate threats, but the scientific evidence is ever more conclusive. The overwhelming majority of scientists, including those working under Trump (USGCRP, 2017, 2018), emphatically state that climate change is occurring, has enormous ramifications and is related to human actions. ${ }^{2}$ Every day brings new and dramatic reports that these changes are costing thousands of lives and billions of dollars in damages.

\footnotetext{
2 "Thousands of studies conducted by tens of thousands of scientists around the world have documented changes in surface, atmospheric, and oceanic temperatures; melting glaciers; disappearing snow cover; shrinking sea ice; rising sea level; and an increase in atmospheric water vapor. Rainfall patterns and storms are changing, and the occurrence of droughts is shifting" (USGCRP, 2017, p. 35).
} 
Scientists generally agree that an average increase of $2^{\circ} \mathrm{C}$ above pre-industrial levels constitutes an absolute boundary for international climate and that even this increase could have extremely dangerous consequences ${ }^{3}$ (HANSEN et al., 2016; UNEP, 2016; CLARK et al., 2016; STEFFEN et al., 2018). Immediate consequences will be most damaging for the poor population, but the repercussions will be worldwide (WORLD BANK, 2016a, 2016b; USGCRP, 2018), and possibly irreversible (USGCRP, 2017; STEFFEN et al., 2018). Average temperatures of the Earth's continents and oceans in 2016 were $1.1^{\circ} \mathrm{C}$ above the pre-industrial average. Though the next two years showed a slight decline, record temperatures are expected again in 2019, which began with unprecedented melting in Antarctica. ${ }^{4}$ Greenland ice melt appears to be reaching irreversible tipping points. ${ }^{5}$ Over the past three decades, the Arctic has lost $95 \%$ of its oldest ice due to warming air and ocean temperatures. Such changes will have cascading effects ranging across a wide spectrum of issues, from severe weather conditions and rise of sea levels to the destruction of marine ecosystems (NOAA, 2018).

The latest and typically conservative IPCC Report (IPCC, 2018) cautions that warming from anthropogenic emissions will persist for centuries to millennia. Recent US government reports advise that, without major reductions in emissions, the annual average global temperature could increase by $5^{\circ} \mathrm{C}$ relative to preindustrial times by 2100 (USGCRP, 2017). All this suggests that the recommended warming limit of $1.5^{\circ} \mathrm{C}$, set at the Paris Climate Agreement in 2015, will soon be exceeded, with further increases following shortly.

Figure 2 shows the robust correlation between the rise in carbon emissions and increases in global temperatures. The use of fossil fuels has helped intensify the concentration of carbon dioxide $\left(\mathrm{CO}_{2}\right)$ in the atmosphere, which peaked at the unprecedented level of 400 parts per million (ppm) for the first time in 2014, and is likely to remain above those levels in the foreseeable future (NOAO, 2017; HANSEN et al., 2016; SCIENCE ADVANCES, 2016). After plateauing briefly, fossil fuel emissions rose by $1.7 \%$ in 2017 and by an estimated $2.7 \%$ in 2018, to 37.1 billion tonnes of $\mathrm{CO}_{2}$ (GLOBAL CARBON PROJECT, 2018). Should present trends continue, the planet's temperature would inevitably rise much more by the end of this century.

\footnotetext{
3 The preservation of island nations actually requires a limit of $1.5^{\circ} \mathrm{C}$, as recommended in COP21.

4 〈http://nsidc.org/arcticseaicenews/〉.

〈https://edition.cnn.com/2019/01/14/world/climate-change-antarctica-ice-melt-twin-studies/index.html〉.

${ }^{5}$ National Academy of Sciences, January 21, 2019.
} 
FIGURE 2

Global warming and $\mathrm{CO}_{2}$ emissions - 1880-2015

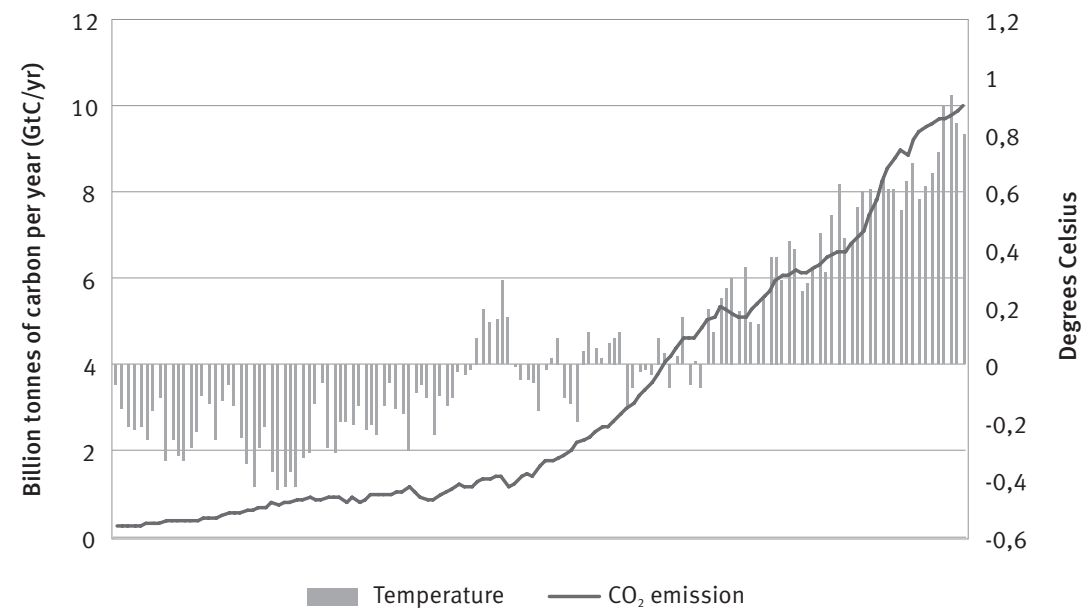

Source: Global Carbon Project (http://cdiac.ornl.gov/GCP/); NOAA (https://www.ncdc.noaa.gov/cag/ /). Visited 06/01/2017

\section{Global drivers and governance responses}

What is being done to stop this fast train to ecological disaster? Essentially - very little! The discrepancy between scientific knowledge and human action on environmental issues is most notorious on the subject of climate change, but is prevalent in all major environmental threats, due to two main and interconnected reasons. First, the nature of global environmental problems stems from a deeply entrenched worldwide quest for economic growth based on a system of production that feeds on a pervasively ingrained culture of consumption. Second, the diffuse and long-term nature of solutions in this domain would require collective action from the global community that transcends the boundaries of national interests and sovereignty, particularly during these unsettled times. These major obstacles warrant further examination.

\section{The culture of consumption, economic growth and development}

The world economy, for a variety of reasons, none more important than China's rapid economic growth, ${ }^{6}$ has experienced an unparalleled increase in recent decades. This has contributed to real improvements in the lives of millions of people. Unfortunately, this growth was based on the wanton transformation of natural resources into waste using a cheap and powerful but polluting source of energy - fossil fuels. Moreover, it was founded on increasing consumption, both through the constant incorporation of new consumers

\footnotetext{
${ }^{6}$ Other obvious factors include the end of the Cold War, India's greater integration in the world economy, China's entry into the World Trade Organization in 2001, the internet and cellphone revolutions and the commodities' super cycle, inter alia.
} 
and the expansion of consumption among existing ones during a period of massive growth in global population.

In a brief essay summarizing his seminal work, Wilk reminded us not only that the consumer culture is at the root of the environmental crisis, but also that consumerism cannot be construed simply as an individual impulse; indeed, it is the product of a political economy that makes it work and grow (WILK, 2017). A constant increase in production via expanded consumption is essential to economic growth. Hence, increasingly effective mechanisms have been devised over time to incite more people to consume more goods and services. These include planned obsolescence of consumer goods, easy credit, plastic money, and access to electronic channels of consumption. Moreover, incessant mass media barrages constantly remind us that we need to buy more stuff in order to be happy. Global advertising revenue was estimated at USD629 billion in 2018 and rising at over 7\% a year (MDG ADVERTISING, 2018). Over time, this combination of incentives has spawned a genuine consumer culture (WORLDWATCH, 2010); this, in turn, has become the most efficient engine of capitalism in promoting economic growth.

Consumption today defines not only the contours of expected happiness, but also the social status of individuals and groups. Consumerism motivates people to increase their income in order to achieve contentment and social acceptance through the purchase of goods and services. Little does it matter that the marginal utility of income tends to diminish and that increased consumption does not guarantee happiness (EASTERLIN, 2001; ASSADOURIAN, 2010; HELLIWELL et al., 2012).

Fomenting consumption that stimulates production and economic growth - even when consumption extends far beyond necessity - remains widely synonymous with "development". This paradigm, given its efficiency, is aggressively promoted, not only by business concerns, but also by national governments and international development agencies. Unfortunately, unlimited production and consumption of goods and services reinforces metabolic throughput flows, increasing resource use as well as emissions. Thus, global material use has tripled over the past four decades (UNEP, 2016, p. 5, 14). Worse, the use of natural resources is projected to increase from 85 billion to 186 billion tonnes between 2015-2050, due to a 28 percent increase in population size and a 71 percent increase in per capita resource use (UNEP, 2017, p. 29). The promotion of consumption, by supporting constant increases in production that give form, content and vigor to "development" has also generated the major threat to humankind in the 21 st century - global ecological chaos.

\section{Limitations of global governance initiatives on climate change}

Given the magnitude of current threats, altering the course of our headlong dash towards the infringement of planetary boundaries would seem an eminently reasonable undertaking for humankind at this point in history. To achieve this, an effective global enterprise to de-carbonize the economy, free us from fossil fuels, and promote de-growth 
of anthropic activities would be needed. Realistically, however, it is clear that international efforts are pitifully ineffective in these domains, as the following brief review demonstrates.

Three major global conferences (in Stockholm - 1972, and Rio de Janeiro - 1992 and 2012) were convened in order to convince governments of the need for a concerted worldwide approach to sustainable development. The 1972 Summit first drew the world's attention to the significance of environmental issues, but its Declaration and Action Plan went largely unheeded, and both were soon buried under the aftermath of the 1974 oil crisis.

The 1992 Conference - following the acid rain crises in developed country cities and building on the success of the fashionable "sustainable development" concept - garnered the most attention and generated the greatest expectations. In retrospect, however, it is clear that its good intentions and promising declarations were soon submerged under the spread of globalized economic growth that took precedence in the 1990s.

The 2012 Conference attempted to resurrect and revitalize the objectives of the 1992 Earth Summit through the "green economy" approach. These efforts were betrayed by the lack of interest of major players in giving up national sovereignty in favor of global governance goals and by the failure to agree either on the gravity of environmental threats or on efforts to redirect economic goals beyond greenwashing (i.e. false claims of policies or products being environmentally friendly). ${ }^{7}$

Several international treaties have also been signed over the years, the main one being the Kyoto Protocol (signed in 1997, but binding as of 2005) whereby developed countries committed themselves to targets for reducing their emissions of key greenhouse gases. Global emissions have obviously shown no signs of reversal since the signing of this treaty. ${ }^{8}$ Such disappointing outcomes of international agreements are commonplace. Out of ninety such commitments in recent decades, significant progress was registered in only four (UNEP, 2012).

Currently, hopes for sustainability are ostensibly pinned on two main global initiatives spearheaded by the UN: the Sustainable Development Goals (SDGs) and the agreements of the 2015 Paris Conference of the Parties (COP). Unfortunately, as evidenced below, neither can be expected to significantly deflect the present unsustainable course of our civilization.

\section{The structural limitations of the SDGs}

The SDGs were adopted in 2015 as successors to the Millennium Development Goals (MDGs), whose substantive contributions were themselves open to question (MOSS, 2010; THE 169 COMMANDMENTS..., 2015; CARVALHO; BARCELLOS, 2015). The groundwork for the SDGs was laid through many months of consultations with other segments of society,

\footnotetext{
7 A cogent summary of the limitations of the green growth paradigm is provided by Hoffman (2015).

8 The Kyoto Protocol only committed developed countries and the USA never ratified it. The Doha Amendment adopted at the 18th COP created a second commitment period for the protocol that needed ratification by 144 Parties. As of March 2018 , only 109 had ratified it.
} 
including the business sector. The resulting SDGs are encyclopedic, involving 17 goals and 169 targets dealing with a wide range of issues at varying levels of generality.

Despite this broad approach, the SDGs hardly constitute the kind of magic wand likely to re-orient our civilization towards sustainability (MARTINE; ALVES, 2015; KUMI et al., 2014). The SDGs fail to address the deeper structural factors causing either poverty or the infringement of planetary boundaries. As with the MDGs, they focus more attention on contentious goals than on the means to achieve them (OLSSON; HOURCARDE; KÖLHER, 2014). They are designed in such a way that makes radical change on everything from eradicating hunger to inclusive industrialization look like a simple matter of agreeing on what the world ought to be like, and then going out and creating that new world out of 169 desiderata, without regard to structural limitations.

The design, pursuit, identification, measurement, financing or feasibility of proposed initiatives are problematic, but the SDGs' fundamental error is to propose, in Goal Number Eight, the very engine that created our environmental quandary, that is, the promotion of generalized economic growth. This Goal states that economic growth will be "sustained and sustainable" which is both a contradiction in terms and an unattainable objective. Not only does it ignore the limits to growth that ecological economists have long established, but also the very cause of unsustainability.

Generalized economic growth, per se, conflicts with atmospheric limits because the process involves a continually increasing consumption of resources and, more devastatingly, the reduction of sink capacity for carbon sequestration. Instead of sanctifying growth in a system centered on making greater profits by selling more merchandise that exhaust more natural resources in a finite planet wherein the energy flow is entropic, the SDGs should have at least signaled a change in the development paradigm.

The unfettered pursuit of economic growth has already brought humankind to the brink of ecological disaster, despite the fact that only one-third ${ }^{10}$ of the world's current population has actually benefitted from "development". To reduce poverty in the other two-thirds using the present growth model would inevitably multiply pressures on the environment. Moreover, we will soon live in a world of some ten billion people, all naturally aspiring to OECD consumption levels. Failing to incorporate a majority of people into the consumer market would obliterate the SDGs' pretensions of reducing inequality. Achieving even half the level of OECD living standards for all human populations through the growth paradigm would shatter planetary boundaries (MARTINE, 2018).

\footnotetext{
9 Though the goal is formulated in broader terms as "Promoting sustained, inclusive and sustainable economic growth, full and productive employment and decent work for all," the central objective is "sustained economic growth," which is unfortunately not sustainable under the current paradigm.

${ }^{10}$ The proportion of the world's population in the middle class is $29 \%$ according to PEW Research Center (iKOCHHAR, 2015), $36 \%$ according to McKinsey (2012) and 50\% according to Brookings (KHARAS; KAMEL, 2018). All these sources adopt a varyingly broad and inclusive definition of "middle class".
} 
In short, perpetuation of the universal growth ideology merely aggravates the situation. None of the SDGs' lofty goals is possible without changes to the economic playing field (BIERMANN et al., 2012; GRIGGS et al., 2013). At best, the SDGs should have prescribed economic growth only in regions and collectivities that desperately need it to relieve poverty. Such a recommendation would not only have signaled a path to the reduction of emissions, but also made more credible inroads towards greater equality. As aptly stated by O'Neill et al. (2018:93): “the pursuit of universal human development, which is the ambition of the SDGs, has the potential to undermine the Earth-system processes upon which development ultimately depends [...] A more hopeful scenario would see the SDGs shift the agenda away from growth towards an economic model where the goal is sustainable and equitable human well-being".

In sum, beyond the many theoretical and operational difficulties of the SDGs, the formulation of Goal \#8 gravely underestimates inherent obstacles in the domain of political economy that have frustrated all sustainability efforts to this point, while implicitly overrating the miracles to be operated by the markets.

\section{Advances and limitations of the UNFCCC and COP21}

The second major environmental initiative by the world community today involves a series of global meetings called Conference of Parties (COPs), organized by the UNFCCC (The United Nations Framework Convention on Climate Change). A total of 24 COP meetings have been held at this writing, and the only one to achieve any meaningful action on climate change was the 2015 COP21, held in Paris. There, some 195 countries gathered again to negotiate a new agreement on climate change. COP21 recorded some progress, reflecting the fact that more people agreed that something should be done to limit climate change caused by human activity. It reached a theoretical consensus on essential points, the main one being that temperatures should not be allowed to rise more than $2^{\circ} \mathrm{C}$ beyond the average temperature of the pre-industrial period, and recommending the safer limit of $1.5^{\circ} \mathrm{C}$. Moreover, instead of mandating universal limits on the emission of greenhouse gases - which have been habitually ignored by signatories - individual countries pledged their own emission caps, under the assumption that this approach would lead to more realistic commitments that countries would, for once, honor.

Nevertheless, COP21 provides little practical grounds for hope. The flexibility of commitments has made it easier for countries to transgress proposed limits. Even in the unlikely event that all countries honored their Paris commitments, the sum of their anthropic activities would still raise average global temperatures by $3^{\circ} \mathrm{C}$ or more by the end of this century, and lead to further rises after that (HANSEN et al., 2016; UNEP, 2015). Scientists recognize that the $2^{\circ} \mathrm{C}$ ceiling will be reached much sooner than expected and that this maximum itself could be catastrophic: "Even if the Paris Accord target of a $1.5^{\circ} \mathrm{C}$ to $2.0^{\circ} \mathrm{C}$ rise in temperature is met, we cannot exclude the risk that a cascade of feedbacks could push the Earth System irreversibly onto a 'Hothouse Earth' pathway” (STEFFEN et al., 2018). 
In brief, COP21 was much too little, too late. It failed to address critical issues - including reliance on fossil fuels, legally binding emission targets, specifics on financial support, liability provision linked to financial compensation for loss and damage - and generally let rich countries off the hook (CLEMENÇON, 2016). As with the SDGs, Paris failed to propose, in any form, the curtailment of economic growth or the redirection of "development". ${ }^{11}$ Given the enormous disparities between countries and groups, a radically different economic model based on the convergence of throughput and carbon emissions would have been imperative in global initiatives such as the SDGs and COPs. The notion of prosperity without growth (JACKSON, 2009) should have been vigorously promoted as a first step in changing basic parameters. ${ }^{12}$ At a minimum, international initiatives should have signaled a movement towards a steady-state economy and de-growth - not as a traumatic and disorganized inverted mirror image of "economic growth", which would create depression and unemployment - but as a more selective process. Therein, sustainable energy would be subsidized, consumption and the pursuit of happiness would be redefined, while economic growth would be restricted to poor countries or groups.

Follow-up activities to the Paris COP, including COP24 in 2018, have further highlighted the enormous discrepancy between goals and national commitments. First, the decarbonisation targets proposed by individual countries are not being met, while economic growth and throughput activity continue to prevail in development strategies. Second, the dismissal of the Paris agreement by the USA, a key player and major polluter, is inspiring other key countries, such as Brazil, to disparage environmental threats and obligations.

\section{Other multilateral initiatives}

Given the dwindling legitimacy and influence of the traditional UN organizations, it would seem logical for other multilateral efforts, particularly those in the economic domain - such as UNCTAD, Davos, APEC, G7 and G20 - to shoulder a greater burden in curbing the threats caused by the intensive deterioration of our natural systems. Evidently, naysayers such as Trump, Bolsonaro and other world leaders put a severe damper on any such initiative. However, the problem goes even deeper since all countries and international development agencies themselves are, to a greater or lesser extent, intent on the pursuit of "development" and since this continues to be defined and characterized primarily by efforts in throughput growth fueled by consumption.

\footnotetext{
11 Again, explicit discussion of the limits to growth, analyzed by a long list of ecological economists as far back as John Stuart Mill, was avoided in COP21. In view of clear impending limits today, "sustained and sustainable" economic growth is doubly problematic.

${ }^{12}$ The notion of "progressive structural change", coined by ECLAC (2016), would also have expanded the discussion. This aims simultaneously at the incorporation of more knowledge into production, ensuring social inclusion and combatting the negative impacts of climate change.
} 
In November of 2018, the difficulties in establishing multilateral agreements concerning the environment were dramatized during both the APEC meeting in Port Moresby - when world leaders of the Asia Pacific region failed to reach a consensus - as well as in the G20 Summit held in Buenos Aires, which was polarized by the commercial war between the USA and China. Early in 2019, negotiations at the Davos WEF also crumbled as a huge internal governance crisis caused the USA to cancel its delegation's participation.

\section{The growing crisis in global governance}

The above discussion exposes the ineffectiveness of global structures in dealing with major planetary crises such as climate change. Why, after such a promising start in the 1990s, have international institutions and multi-country commitments become so feeble and ineffectual? The answer is that global governance, like national and local governance, is ultimately defined by politics, and the current political ambience is not conducive to the promotion of international institutions and objectives. This is particularly true in policy domains that threaten consumption-based development.

World conditions have changed drastically since the creation of the United Nations, severely outdating the overall structure of multilateralism while also limiting the willingness of countries to cede part of their sovereignty to multilateral organizations. Global structures derive their power from concessions made on national sovereignty and from mandates granted by constituent countries, who allocate a segment of their decisionmaking to an independent global governance body and provide it with the legal, political and financial means to exercise independent authority on key international issues. The multiplication of relevant global actors with dissimilar agendas, the proliferation and complexity of real issues, the increasingly diffuse nature of agency programmes, coupled with bureaucratization of the system, have accentuated structural inadequacies and the inability of existing organizations to deal effectively with the growing number and intensity of major global problems. This expanding gap between the scale of global crises and the political, financial and technical capacity of existing institutions to solve them argues for urgent revamping and strengthening of the existing framework.

The deficiencies of multilateralism are being amplified by two concomitant but antagonistic forces, whose nucleuses are localized in the world's most powerful countries - the United States and China. The USA headlines a major thrust towards nationalism and chauvinism among several market economy countries in the Western Hemisphere, Europe and Asia. Meanwhile, China is promoting a sweeping campaign in Eurasia to boost economic growth and transform the global trade network that supplies China while providing a market for its products. Both movements, and the ongoing commercial war between the two major powers, pose significant threats for global governance and for our environmental future. 


\section{National populism and global divisionism}

The very mechanics of unabashed freewheeling economic competition during the recent globalization cycle, together with the friction generated by inequality and loss of identity in this era, have eroded the willingness of many developed and developing countries to make concessions to global governance. Greater competition among countries and among cities to attract international investment has increased the influence of both foreign governments and Transnational Corporations (TNCS) on the economy of individual countries, thereby weakening autonomy in national decision-making. TNCs lobby for privileges, subsidies and tax cuts, practice tax-avoidance, negotiate "sweetheart deals" and other devious schemes with compliant governments. Such manipulations whittle away at national autonomy, shrinking countries' leeway for maneuver in conceding sovereignty to multilateral institutions, muddying the waters of international relations, and ultimately reducing the potential influence of multilateral organizations.

At a more profound and enduring level, the elimination of trade barriers in order to promote growth has also helped spark strong emotional discontent in both developed and developing countries, and these sentiments are at the root of major political upheavals that powerfully affect national sovereignty at the present time. Open international trade helped several developing countries grow and this contributed to undeniable improvements in living standards for many. Yet, globalization has also failed to bring stable economic improvements to all. In addition to restricting national autonomy in decision-making and producing unequal economic results, globalization also introduced pervasive cultural elements resented by more traditional societies (BARRIOS et al., 2003; STIGLITZ, 2002). Dissatisfaction with the implementation of the free trade model was also catalyzed by the devastating impacts of military interventions and subsequent internal conflicts which failed to bring closure to any of the issues they were purportedly addressing, while escalating disorder and massive human suffering in their wake.

Endless conflict, persecutions and human misery are not only encouraging terrorism, but also driving millions of desperate people to seek refuge elsewhere. Increased awareness of such world and national events, facilitated by the massification of personal and media communications, has fueled resentment, fostering a variety of counter-reactions, including fundamentalism. In light of these foreseeable consequences, the political and economic turmoil that has intensified in several developing countries over recent years was inevitable.

Yet, what is even more striking is that discontent with globalization has spread to the world's advanced economies and is having a shocking influence on their governance as well. For many, neither free trade nor democracy have clearly fulfilled their promises. Powerful interests at both the private and country level have become increasingly critical of globalization and even become prominent defenders of radical nationalism (CHICAGO COUNCIL ON GLOBAL AFFAIRS, 2016). Moreover, trade is a major source of discontent 
among large segments of the population in advanced countries who have not been doing well (STIGLITZ, 2016).

An important study from the Mckinsey Global Institute showed substantial income drops across the board in developed countries (DOBBS et al., 2016). Since World War II, dynamic economic growth allowed the population of the 25 most advanced economies to enjoy constant and real increases in income, except for a brief interruption in the 1970 s. Between 1993 and 2005, 98\% of families in those countries had experienced increases in real income. In contrast, during the 2005-2014 period, as shown in Figure 3, approximately two-thirds of all families in the 25 most advanced economies, amounting to some 540 million people, suffered stagnated or decreased income. Young people and least-educated workers have fared the worst.

FIGURE 3

Percentage of population in groups with flat or falling market income (1)

Selected countries - 2005/2014

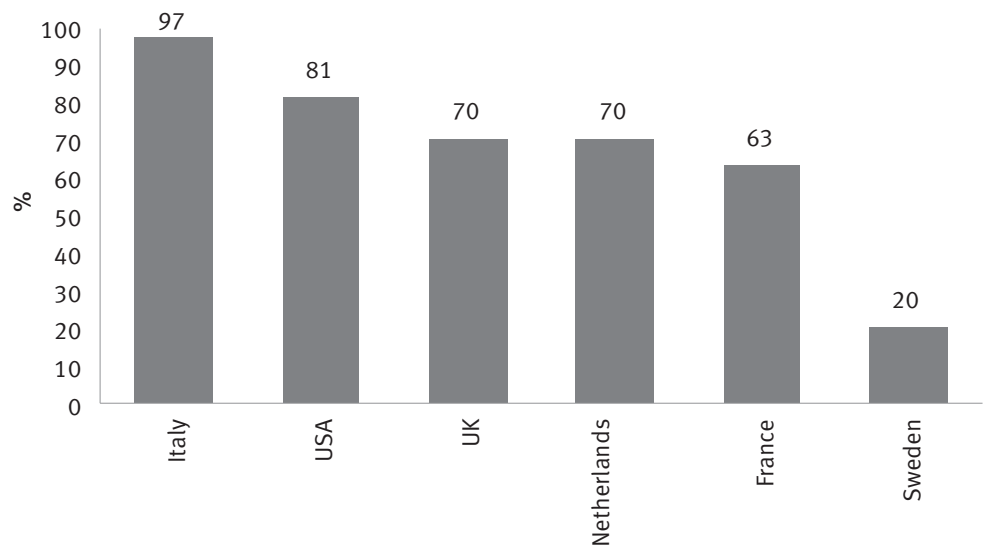

Source: Based on McKinsey Global Institute Analysis (DOBBS et al., 2016).

(1) 2014 or latest available data for market income (wages and income from capital); population measured in income deciles.

Stagnation of economic mobility has come as a shock in advanced economies and has even brought an increase in midlife mortality rates among less-educated white Americans (CASE; DEATON, 2015). In objective terms, current generations in advanced economies are not lacking comforts and ability to consume, especially when compared to corresponding cohorts in developing nations. Nevertheless, frustration, anxiety and anger are surging from the rise of an absurdly rich plutocracy, from within-country inequality and from the inability of current generations to advance or hold expected income and living standards.

All this has spawned diffuse but critical forms of protest under globalization. Reactions are furious and simplistic while also revealing flaws in the practice of democracy. The space formerly reserved for statesmen is being occupied by populists who establish a relationship with the masses by playing on their deepest prejudices and fears (ECO; MCEWEN, 2014, p. 146). These new politicians, who have themselves frequently benefitted from 
unconstrained trade liberalization, are given a platform from which to attract voters with fanatical but alarmingly naive schemes, such as blaming the social advance of minorities for current problems. All this contributes to the disruption of established national governance and fosters international xenophobia.

Free trade, open borders and immigration are not the main causes of this predicament. True, the reduction of jobs in rich economies due to technological innovation and outsourcing is real under globalization. Yet, the financial follies of the American banking complex that almost brought down the world's economic system in 2008, and that have dulled growth, employment and security ever since, played a much larger role. Moreover, the angst spawned by interventionism by the two countries that recently led the charge against globalization and multiculturalism is another pertinent factor. Indeed, as has been aptly observed - "In both the US and the UK, the Iraq war is now seen as having illegitimate origins, incompetent management and disastrous outcomes" (WOLF, 2017).

Trump, Brexit proponents and a growing number of other world leaders have taken advantage of the anti-globalism sentiment to promote a populist agenda that highlights protectionism, deregulation and rejection of multilateralism, while also defending such values as militarism, racism, misogyny and climate change denial. They are aggressively attacking multilateral organizations and advocating for unilateral rupture of their countries' ties to them, while also urging anti-immigration policies.

In short, the unparalleled escalation of inequality and discontent - in the context of a world increasingly connected and aware, marked by strong cultural and religious cleavages is eroding the very roots of both traditional autocracies and established democracies. When coupled to the real decline in national sovereignty brought on by economic globalization, protectionism prevails and multiculturalism fades. The irony is that protectionist measures will neither generate prosperity nor peace, and much less reduce environmental threats.

\section{Fragmented globalization under Chinese control}

While globalization is losing public and political support elsewhere, China has launched a bold initiative that proposes to boost global trade and economic growth, mainly through the construction of a massive infrastructure plan named (BRI): Road and Belt Initiative (CIMB ASEAN RESEARCH INSTITUTE; LSE IDEAS, 2018). Since 2013, China has been working with global and regional development banks to integrate the vast Eurasia region by boosting trade and promoting infrastructure buildup across a large number of countries. Investments entailing many billions of dollars for countries touched by the BRI are building high-speed railways, motorways, refineries, bridges, power plants and industrial parks. A freight route stretching over 12,000 kilometers between China's eastern coast and London already allows cargo to be shipped across Eurasia in record time.

Both developed and developing countries are benefiting from China's munificence. This umbrella initiative is stimulating economic growth and intensifying the movement of 
people and resources across Eurasia while earning enormous political gain for China. One particularly significant strand of China's growing influence over an enormous geographical territory is in the field of Science. Many low- and middle-income countries, from Sri Lanka to Chile, are already drawing support for scientific research on a wide variety of issues. This constitutes not only a huge boost to scientific research in these countries but also a profound shift in the intellectual roots and baseline perspectives of scientific research traditionally centered in Western countries and Japan (MASOOD, 2019).

There can be little doubt that the growing influence of the BRI network represents a major swing in the global locus of political and economic power. The fact that this fateful transfer is occurring at a time in which a populist government in the United States is openly embracing nationalism, and unwittingly relinquishing its domineering role on the international stage, makes it doubly meaningful for global governance and environmental change. Given the current populist ambiance in much of the world and the commercial war unfolding between China and the USA, a new scientific and technological "Cold War" could ensue, as attested to by the recent Huawei imbroglio.

The consequences of the ongoing shift in the global locus of economic, political and scientific activity are both promising and ominous, given the complex legal and environmental issues involving the BRI. It is widely accepted that the BRI will increase productivity and reduce poverty over a vast region. At the same time, critics suggest that China has a checkered record in international economic dealings. In this perspective, the BRI's efforts to help promote economic growth and trade over a wide range of countries would constitute a ploy for China to export its industrial overcapacity, while smothering participating countries in debt. Even the massive boost to scientific research promoted by China has raised alarm about the transfer of valuable and sensitive resources (MASOUD, 2019).

Meanwhile, the BRI undoubtedly faces growing challenges around business contracts with partner countries having different legal systems. Given the fact that global governance is at a low ebb, China will likely have to assume much of the burden of regulating increasingly complex transactions.

Environmental issues are sure to be at the root of many difficult negotiations. It is true that China has made great strides in the realm of renewable energies. The BRI could also lead to a somewhat better allocation of natural resources when, for instance, China replaces petroleum from the Middle East and Nigeria with less-polluting natural gas from less-distant Tajikistan and Siberia. Nevertheless, the BRI is paving routes through ecologically fragile habitats. More generally, fossil fuel and mineral resources are being exploited at an intensified pace in the region through the BRI. Ultimately, the fundamental overarching problem is that the integration of Eurasia will increase regional and global GNP via throughput growth and inevitably enhance environmental degradation while contributing to climate chaos (LAURANCE, 2018). 


\section{Impacts of the global governance crisis on climate change policy}

The foregoing discussion makes it clear that global governance, which was already suffering from dispersion of sovereignty and the unequal distribution of benefits under globalization, has now reached a critical turning point. Both developed and developing countries are going through severe internal governance crises and, hence, their decisionmaking process, whether on global or national issues, is also in considerable disorder. Nationalism and protectionism are the Pavlovian response to felt challenges, despite the acuteness of global issues. Exacerbated economic competition among major powers is threatening world peace. As noted by Wolf (2017) "the lure of false solutions generated by disillusion and rage could even destroy the intellectual and institutional pillars of the postwar global economic and political order".

This situation obviously does not bode well for the resolution of critical issues such as climate change. The additional fact that the elected president of the world's most powerful nation is both a deregulation fanatic as well as a radical skeptic of climate change, ${ }^{13}$ who reneges on the USA's promises and commitments regarding the environment, paints a nightmarish scenario. Trump's flagrant negativism has emboldened other world leaders to turn their backs on their already-feeble environmental pledges, allegedly in order to secure their own country's economic growth. For instance, Brazil, a vital constituent of the global ecological scenario, recently elected a government that considers climate change to be a Marxist conspiracy, while facilitating deforestation, the exploitation of vital ecological reserves and the relaxation of minimum standards on the use of agrotoxics in order to benefit its agribusiness lobby.

What possible solutions to this global quandary can be foreseen? Two very distinct pathways can be visualized. Reduced to essentials, the first of these assumes that "business as usual", given the inherent capabilities of market forces, and particularly their proficiency in developing technology, will be sufficient to overcome whatever natural hurdles come up on the road to continued "development". A second pathway considers that awareness raising will be necessary to change the very meaning of "development" before sustainability can be achieved. Therein, a drastic change in the dominant political economy, leading to dramatic transformations in consumption patterns, will be necessary in order to avoid further risky transgressions of critical planetary boundaries. Motivation for this revolution could theoretically come through massive and databased advocacy. Yet, it is more likely to arise from the anxieties caused by the multiplication of extreme weather events and tangible massive ecological disasters.

\footnotetext{
13 Trump's positions directly clash with the latest scientific reports prepared under his own administration (Cf. USGCRP, 2017, 2018).
} 


\section{Technology, markets and their environmental limitations}

Paradoxically, faith in the miracle of the markets loosely connects polar opposites such as the SDGs with right-wing politicians and development optimists. It is largely based on the belief in the power of human ingenuity and its capacity to develop technological solutions to all problems, including the infringement of Nature's limits. There can be no doubt that technological advances will be crucial in any attempt to avoid an impending ecological chaos. For instance, the market for renewable energies is booming, and presents excellent opportunities for merging technological change with market dynamics in support of sustainability. Yet, while innovations in the energy sector are indeed critical, a huge amount of energy is required to develop and deploy an alternative system. Moreover, other materials besides oil are also finite, as is the case of lithium and cobalt - essential minerals for the success of such promising ventures as renewable energy storage and electric cars whose known reserves could be quickly depleted (HUNT, 2015; VICKSTRÖM et al., 2013). In short, as aptly summarized by Tverberg (2014, p. 1) - "In a finite world, we are reaching many limits besides fossil fuels [...] the danger in almost every solution is that we simply transfer our problems from one area to another".

The velocity and magnitude of technological development over the last few decades is impressive. Thirty years ago, very few people had access to a computer and nobody owned a cellphone. Now, the majority of the world's population has a mobile phone and a large portion also has access to computers. However, even this positive trajectory has had its environmental costs. Thus, the implementation of cloud computing involves tremendous energy consumption and increases of carbon dioxide emissions (UCHECHUKWU et al., 2014). In 2016, data centers already accounted for some $2 \%$ of all energy consumed in the USA (SVERDLIK, 2016). The collective energy needed to power Bitcoin via computers and server farms all over the world has generated considerable alarm. Progress in energy efficiency is more than neutralized by the rapid growth of digital content, big data, e-commerce, and Internet traffic: Data centers are now a key driver in the construction of new power plants (DELFORGE, 2014).

More generally, all technological advances have inherent limitations and conditioning factors. The Jevons Paradox continues to prevail, in the sense that efficiency improvements are continually offset by increases in scale; each new technological advance, upon enhancing the efficiency of a natural resource, intensifies its total use instead of reducing it (POLIMENI et al., 2008; ALCOTT, 2005; OWEN, 2010).

Enormous progress was made over the course of the 20th and 21st centuries in the use of resources and the energetic efficiency of economic growth. However, this progress has resulted in increased production and consumption, instead of reducing environmental impacts. The widely ignored critical fact is that, during this recent period of fantastic technological advances, the use of the Earth's materials has expanded at a faster rate than at any other time in history. Material productivity is actually stagnant or decreasing. The 
annual global extraction of materials increased from 22 to 70 billion tonnes between 1970 and 2010, while per capita global material use increased from 7 to 10 tonnes (UNEP, 2016, 2017). As a result, global carbon emissions are still growing and some 20 billion tons of heat-trapping carbon dioxide are being thrust into the atmosphere each year.

Upcoming environmental threats may soon be well beyond the capacity of human technology since they involve pressure on interlinked planetary boundaries that, once exceeded, detonate state shifts of unknown nature and dimensions (BARNOSKY et al., 2012; USGCRP, 2017; STEFFEN et al., 2018). Technology is, at best, a necessary but partial component in the solution of today's global problems. It simply has no autonomous influence on the resolution of the multiple social, religious, geopolitical and economic conflicts that have multiplied over recent decades and that underlie the current futility of global governance. Technological development has undoubtedly improved human lives, but its effects can depend on capricious, misguided or even malevolent human manipulation.

Faith in technology is universally attractive simply "because changing technologies is much easier than altering societies and their socio-economic drivers" (HOFFMAN, 2015, p. 2). Reification of the capacity of technological advances to redress the course of human organization is not only naïve but potentially destructive. Wagering the future of the Earth and its inhabitants on technological innovations, rather than promoting essential changes in the political economy of development, is the most dangerous and encompassing form of Russian roulette in humankind's history.

Technology is not neutral; it is generated, sold, bought and manipulated in accordance with someone's interests. Even the most progressive and potentially beneficial technologies are managed by someone in view of some objective. Advances in electronic communications have changed the lives of billions of people positively and yet, as recent incidents with Facebook and other highly touted electronic "miracles" have shown, they have also led to cyber insecurity, loss of privacy, fraud and threats to financial activity, disinformation campaigns and even interference in the course of major elections. The fields of weaponry and armament are among those that have made the most impressive technological progress in recent decades, and some of those advances can have beneficial civilian uses. More to the point, however, these innovations are being primarily used in massive human slaughter and are under the control of some of the most volatile leaders in recent history.

Who is to control the use and misuse of technology? During the recent period of amazing technological development, governance capacity at the local, national or global level to deal with worsening crises - some of which are attributable to technological development itself - continues to deteriorate. Terrorist groups are not the only source of danger. Some of the world's most powerful leaders show not only disdain for environmental concerns but also a stated disposition to protect national interests at all costs with their superior technology in weaponry. New technologies are now a prime source of economic strength and military security. They can trigger a new Cold War as seen in the recent China/USA competition over smartphone $5 \mathrm{G}$ technology. In this light, the personages currently in 
control of the latest technology in nuclear armaments do not inspire greater security in the future of humankind. Ultimately, the potentially destructive pitfalls stemming from artificial intelligence themselves generate considerable anxiety.

In short, without changes in the very notion of development, as well as in the values and ideology it embodies at the global level, technological advances are critical but insufficient. The extreme faith that authors such as Diamandis and Kotler (2012), Rifkin (2014) and others placed in technology "represents techno-utopianism at its worse" (OGDEN, 2012). Such stances lull us into thinking that technological band-aids could somehow solve all our increasingly thorny political, economic and environmental difficulties, and that we can thus continue to abuse Nature's resources with impunity (HUESEMANN; HUESEMANN, 2011). Even less aggressive stances, such as those reflected in the SDGs' implicit promotion of technology when supporting universal economic growth, also promote dangerously false expectations.

\section{Awareness raising, post-truth and decision by disaster}

Given the limitations of free market forces and their technological advances, what is going to prevent further irreparable transgression of planetary boundaries? Unfortunately, there is no quick and easy fix to redirect the trajectory of civilization towards a more sustainable path. Actually, what needs to be done - abandoning the universal value currently placed on unfettered and generalized economic growth fueled by increased consumption - is essentially unattractive to the general population and thus to policymakers elected by them. Vigorous negationist campaigns are obviously sponsored by powerful right-wing lobbies, but their impact builds on widespread support from nationalistic sentiments (MARQUES, 2019), as well as from the unease inspired by the imagery of a post-consumerist society. Sustainability would require people to re-appraise their consumption patterns and prioritize non-material goals such as health, security, culture, artistic expression, knowledge, friendship, community, solidarity and other similar values. Such a change towards alternative sources of hedonism strikes at the very heart of deeply ingrained values and the lifelong personal commitments to material objectives instilled in us at birth throughout our "civilization" by the culture of consumption.

To produce such a transformation in values and pursuits not only requires going against the grain of the dominant culture but, more importantly, questioning and opposing a well-established political economy and the system of social organization that supports it. Ultimately, it is clear that not enough people are sufficiently motivated to force policymakers to address the connection between climate change and the economy, and much less to force their politicians to cede sovereignty to some international entity on these matters. Despite repeated and consistent warnings about climate change from the scientific community, public opinion is more easily swayed by negationist propaganda, because it relieves people of the obligation to change their behavior or confront complex issues regarding the prevalent development paradigm. In the USA, for instance, it is reported that most 
people are now aware of climate change, yet only a small number are actually alarmed by it or demand immediate action. ${ }^{14}$

Without popular pressure, very few of the richer nations - and none of the developing countries - are willing to concede significant power to any global structure that would somehow restrict their "right" to promote "development" through economic growth. Agreements to change the course of carbon-intensive growth would require effective political forces fully committed to structural transformations. These do not exist at the moment.

What could spark the motivation to generate the political mobilization capable of altering the world's commitment to consumption and indiscriminate economic growth? Should humankind continue with a business-as-usual approach, it will eventually encounter a powerful source of motivation stemming from an inevitable intensification of the frequency and violence of extreme weather events and far-reaching environmental disasters. By that time, of course, corrective policies will have to be much more drastic, costly, difficult to implement and of more doubtful efficacy.

To forestall this "decision by disaster" approach, one potential pathway to garnering the political momentum capable of altering humankind's trajectory to environmental chaos would be to use massive information and advocacy campaigns leading to a better definition and appreciation of viable pathways to sustainability, and also to more effective activism. In this regard, as observed by philosopher Umberto ECo (ECO; MCEWEN, 2014, p. 143) - "consensus is managed through the most pervasive information media." The commercial media constitutes a formidable lobby; it influences the public by sharing news and information with an opinionated perspective, which, in turn, shapes political behavior. Currently, it is being intensively used to perpetuate a dominant culture of consumption and an economic system that is inimical to sustainability. Somehow, this will have to change, if we are to avoid ecological chaos.

Countering the system in place, firmly secured by a constellation of coordinated forces and vested interests, is evidently problematic. Powerful corporate lobbies are adroit at using arguments aimed at "safeguarding our way of life" and "guaranteeing the well-being of our citizens" as justification for the promotion of their own short-term interests at the cost of global concerns. They exert a formidable influence on legislative bodies to control internal and international politics, even in long-established democracies. At the same time, they manipulate the knowledge, values and preferences of voters through propaganda from their vast communications operations, giving substance to the notion that we live in a post-truth and post-fact society.

\footnotetext{
$\overline{14}$ For instance, a study by PEW Research Center (2016) shows that politics is the central factor shaping people's beliefs about climate change in the USA. The majority of people do not trust climate scientists and less than half believe climate change is due to human activity. Although $38 \%$ of Americans say they care "a great deal" and another $36 \%$ care "somewhat" about climate change, only $11 \%$ follow news of climate change "very closely" and $40 \%$ consider that reporters do not pay sufficient attention to skeptics of climate change. Only two in ten see themselves as always making an effort to live according to their environmental concerns.
} 
For instance, it seems inconceivable that so few people are realistically aware of the livestock industry's impact on greenhouse gas emissions. Replacing ruminant meat with better alternatives would be one of the least painful ways of effecting significant and rapid impact on the reduction of greenhouse gases, as well on the improvement of global health. Multiple studies demonstrate that the direct and indirect effects of livestock and their by-products account for a substantial and increasing proportion of annual worldwide GHG emissions. A recent report by the World Resources Institute (2018, p. 19) states: "If global consumers shifted 30 percent of their expected consumption of ruminant meat in 2050 to plant-based proteins, the shift would, by itself, close half the GHG mitigation gap and nearly all of the land gap".

More recently, an international commission of scientists developed a "planetary health diet" based on cutting red meat and sugar consumption in half and increasing the intake of fruits, vegetables and nuts. Such a radical but viable change would reduce further damage to the planet, improve the health of the world's population and ensure sustainable food production (WILLETT et al., 2019; ROCKSTRÖM; STORDALEN; HORTON, 2016). Reducing meat consumption is certainly one of the least traumatic changes that would have a significant effect on climate change and human welfare. The lack of awareness or public discussion surrounding such a critical matter is traceable to the unwillingness of meat-eaters all over the world to reflect on their consumption patterns, but it also speaks of powerful lobbies at work in the dominant political economy. For instance, Brazil's recent election of a populist president led to an immediate shift towards anti-environmental and pro-agribusiness policies aimed at heightening the production of commodities and, thereby, economic growth rates (i.e. - "development").

Most of the oil and mineral industries persist in their long-established efforts to negate the scientific evidence concerning their impact on climate change and to sponsor a variety of skeptical voices. Since their message comforts people with the notion that they are free to continue consuming and that such consumption actually contributes to the welfare and economic strength of their nation, it is extremely effective, not only in perpetuating unsustainable behavior, but also in electing officials who will forcefully deny the need for environmental stewardship.

Countering such powerful and comforting voices is certainly not an easy task, given the strength and perniciousness of their speakers. Part of the negationist strategy - as in the vicious campaigns of the tobacco industry some decades ago - involves destroying the credibility and even the personal and professional lives of those who oppose them. Papers alerting to the risks of climate change, even in the most trustworthy peer-reviewed scientific journals, are immediately struck with vitriolic personal and professional attacks funded by the negationist lobby. ${ }^{15}$

\footnotetext{
15 Monbiot (2016) cites a number of bloggers and institutes funded by oil and coal companies to whip up fury against climate scientists and campaigners.
} 
Countering this segment of the post-truth society is critical. Use of the social media is an obvious alternative, given its record of generating spontaneous mass movements of extraordinary impact. Ideally, it could become a powerful force in promoting sustainability. Unfortunately, negationists are already using this media most effectively. Ultimately, it behooves upon the environmental movement to present the post-consumerist sustainable society in terms that are more attractive and to multiply more effective science-based advocacy to counter the combined influence of the dominant political economy and its consumer culture, as well as the skeptics' propaganda. Unfortunately, support for effective action may ultimately depend on more extreme climate-driven events. Ironically, that is sure to come soon, though too late for effective painless action.

\section{Conclusion: Governance crises, climate change and multilateralism}

Our so-called civilization is facing a titanic storm and we lack a beacon to guide us to a safe harbor. Globalized economic growth was slated to bring well-being to the world's population but generated new inequalities and socio-political friction along with environmental degradation. The promise of "sustainability" has been shattered against the wall of a political economy that requires constant increases in consumption for "development".

Our lifestyles within "development efforts" are resulting in a dangerous transgression of planetary boundaries. Climate change and critical loss of biodiversity are occurring at an exponential rate that defy easy solution. Assessments from scientists in the US government suggest three main solutions: setting a price on greenhouse gas emissions; establishing government regulations on acceptable limits to greenhouse pollution; and spending public money on clean-energy research (USGCRP, 2017, 2018). These are all important but insufficient steps; massive emissions cuts could only be attained through drastic changes in basic values and in the deeply ingrained ideology that promotes consumer culture and sustained economic growth as the only road to "development".

Solid global political pressure will be essential to force policymakers to act for the common good rather than business-as-usual. The combination of serious environmental and social alerts forces us to reject the frivolous argument that human ingenuity, market mechanisms and technological development per se will somehow be enough to overcome whatever crises arise (CLEMENÇON, 2012; THAKUR, n.d.). Ultimately, the solutions to humankind's problems are not merely technical or economic; they require good will, solidarity, empathy and cohesion, as well as an altruistic and longer-term vision in pursuit of the common good embodied in a different "development" path.

Strong multilateral institutions are increasingly needed - not to promote traditional narrow agendas - but to help identify key issues and summarize, mediate, prioritize and channel the pressing concerns of global society in an unbiased and altruistic manner towards effective solutions. The United Nations continues to represent the embodiment of multilateralism, but its overall legitimacy cannot be simply perpetuated by allowing 
corporate interests to have a disproportionate influence over the bodies that write global rules (ADAMS; MARTENS, 2015), nor by broad but ineffective campaigns such as the MDGs or the SDGs. It is unfortunate that such initiatives actually help evade serious discussion of the real and pressing structural issues spawned by our civilization and its dominant development paradigm.

Specifically, international governance of the global commons must be strengthened (GRIGGS et al., 2013; BIERMANN et al., 2012). Discussion of a new governance framework in this domain will continue to meet unrelenting opposition until people in developed countries show a quantum increase in environmental awareness concerning the perils of our unsustainable development, and advocate for better governance. Unfortunately, this may not occur until the effects of transgressing planetary boundaries have become much more violent and indiscriminate in those countries. When such a drastic situation unfolds, more unilateral and draconian forms of control will have to be adopted in attempts to redress the situation. Indeed, it is possible that effective multilateralism will only rise from the ashes of the civilization we know.

\section{References}

ADAMS, B.; MARTENS J. Fit for whose purpose? Private funding and corporate influence in the United Nations. New York: Global Policy Forum, 2015. Retrieved from: ‘https://www.globalpolicy. org/images/pdfs/images/pdfs/Fit_for_whose_purpose_online.pdf .

ALCOTT, B. Jevons' paradox. Ecological Economics, v. 54, n. 1, p. 9-21, 2005. DOI: 10.1016/j. ecolecon.2005.03.020.

ASCENSÃO, F.; FAHRIG, L.; CLEVENGER, A.P.; CORLETT, R.T.; JAEGER, J.A.G.; LAURANCE, W.F.; PEREIRA, H.M. Environmental challenges for the Belt and Road Initiative. Nature Sustainability, v. 1, p. 206-209, May 2018.

ASSADOURIAN, E. The rise and fall of consumer cultures. In: THE WORLDWATCH INSTITUTE. State of the world 2010: transforming cultures from consumerism to sustainability. New York; London: W.W. Norton, 2010

BARRIOS, H.; BECK, M.; BOECKH, A.; SEGBERSETL, K. (ed.). Resistance to globalization: political struggle and cultural resilience in the Middle East, Russia, and Latin America. Hamburg: LIT Verlag, 2003.

BARNOSKY, A. D.; HADLY, E. A.; BASCOMPTE, J.; BERLOW, E. L.; BROWN, J. H.; FORTELIUS, M.; GETZ, W. M.; HARTE, J.; HASTINGS, A.; MARQUET, P. A.; MARTINEZ, N. D.; MOOERS, A.; ROOPNARINE, P.; GEERAT, V.; WILLIAMS, J. W.; GILLESPIE, R.; KITZES, J.; MARSHALL, C.; MATZKE, N.; MINDELL, D. P.; REVILLA, E.; SMITH, A. B. Approaching a state shift in Earth's biosphere. Nature, n. 486, p. 52-58, June 072012.

BIERMANN, F.; ABBOTT, K.; ANDRESEN, S.; BÄCKSTRAND, K.; BERNSTEIN, S.; BETSILL, M. M.; BULKELEY, H.; CASHORE, B.; CLAPP, J.; FOLKE, C.; GUPTA, A.; GUPTA, J.; HAAS, P. M.; JORDAN, A.; KANIE, N.; KLUVÁNKOVÁ-ORAVSKÁ, T.; LEBEL, L.; LIVERMAN, D.; MEADOWCROFT, J.; MITCHELL, R. B.; NEWELL, P.; OBERTHÜR, S.; OLSSON, L.; PATTBERG, P.; SÁNCHEZ-RODRÍGUEZ, R.; SCHROEDER, H.; UNDERDAL, A.; CAMARGO VIEIRA, S.; VOGEL, C.; YOUNG, O. R.; BROCK, A.; ZONDERVAN, R. Navigating the Anthropocene: improving Earth system governance. Science, n. 335, p. 1306-1307, 2012. 
CARVALHO, P. G.; BARCELLOS, F. C. Os Objetivos de Desenvolvimento do Milênio - ODM: uma avaliação crítica. Rio de Janeiro: IBGE, 2015 (Textos para discussão, n. 56).

CASE, A.; DEATON, A. Rising morbidity and mortality in midlife among white non-Hispanic Americans in the 21st century. Proceedings of the National Academy of Science of the United States of America, v. 112, n. 49, p. 15078-15083, 2015. Retrieved from: 〈http://www.pnas.org/ content/112/49/15078.full.pdf?with-ds=yes>.

CENTER FOR STRATEGIC AND INTERNATIONAL STUDIES. How will the Belt and Road Initiative advance China's interests? China Power Project. 2019. Retrieved from: «https://chinapower.csis. org/china-belt-and-road-initiative/>.

CIMB ASEAN RESEARCH INSTITUTE; LSE IDEAS. China's Belt and Road Initiative (BRI) and Southeast Asia. Kuala Lumpur, Malaysia: CIMB Southeast Asia Research, October 2018. Retrieved from: 〈http://www.lse.ac.uk/ideas/Assets/Documents/reports/LSE-IDEAS-China-SEA-BRI.pdf〉.

CHENG, L.; ZHU, J.; ABRAHAM, J.; TRENBERTH, K.E.; FASULLO, J.T.; ZHANG, B.; YU, F.; WAN, L.; CHEN, X.; SON, X. 2018 continues record global ocean warming. Advances in Atmospheric Sciences. v. 36, n. 3, p. 249-252, 2019.

CHICAGO COUNCIL ON GLOBAL AFFAIRS. Public opinion and foreign policy in an unusual election year. October 24, 2016. Retrieved from: 〈https://www.thechicagocouncil.org/blog/globalinsight/public-opinion-and-foreign-policy-unusual-election year?utm_source=Informz\&utm _ medium=Email\&utm_campaign=Gl_10-27-16\&_zs=Tf4rb1\&_zl=xnk03〉.

CLARK, P.; SHAKUN, J. D.; MARCOTT, S. A.; MIX, A. C.; EBY, M.; KULP, S.; LEVERMANN, A.; MILNE, G. A.; PFISTER, P. L.; SANTER, B. D.; SCHRAG, D. P.; SOLOMON, S.; STOCKER, T. F.; STRAUSS, B. H.; WEAVER, A. J.; WINKELMANN, R.; ARCHER, D.; BARD, E.; GOLDNER, A.; LAMBECK, K.; PIERREHUMBERT, R.T.; PLATTNER, G .K. Consequences of twenty-first-century policy for multimillennial climate and sea-level change. Nature Climate Change. Supplementary information, 2016. DOI: 08/02/2016, 10.1038/NCLIMATE2923. Retrieved from: 〈http://climatehomes.unibe. ch/ stocker/papers/clark16natccS.pdf〉.

CLEMENÇON, R. The two sides of the Paris climate agreement: dismal failure or historic breakthrough? Journal of Environment \& Development, v. 25, n. 1, p. 3-24, 2016.

CLEMENÇON, R. From Rio 1992 to Rio 2012 and beyond: revisiting the role of trade rules and financial transfers for sustainable development. Journal of Environment \& Development, v. 21, n. 1, p. 5-14, 2012.

DALY, H. Three limits to growth. Resilience. September 5, 2014. Retrieved from: 〈http://www. resilience.org/stories/2014-09-05/three-limits-to-growth〉.

DALY, H. Beyond growth: the economics of sustainable development. Boston: Beacon Press, 1996.

DELFORGE, P. New study: America's data centers consuming - and wasting - growing amounts of energy. Expert Blog, National Resources Defense Council, August 26, 2014. Retrieved from: 〈https://www.nrdc.org/experts/pierre-delforge/new-study-americas-data-centers-consumingand-wasting-growing-amounts-energy>.

DIAMANDIS, P. H.; KOTLER, S. Abundance: the future is better than you think. New York: Free Press, 2012.

DOBBS, R.; MADGAVKAR, A.; MANYIKA, J.; WOETZEL, J.; BUGHIN, J.; LABAYE, E.; KASHYAP, P. Poorer than their parents? A new perspective on income inequality. McKinsey Global Institute, July 2016. Retrieved from: 〈MGI-Poorer-than-their-parents-Flat-or-falling-incomes-in-advancedeconomies-Full-report.pdf $\rangle$. 
EASTERLIN, R. Income and happiness: toward a unified theory. Economic Journal, n. 111, p. 465-484, 2001.

ECLAC - Economic Commission for Latin America and the Caribbean. Horizons 2030: equality at the centre of sustainable development. United Nations Economic Commission for Latin America and the Caribbean. Retrieved from: 〈http://repositorio.cepal.org/bitstream/ handle/11362/40160/4/S1600652_en.pdf>.

ECO, U.; MCEWEN, A. Turning back the clock: hot wars and media populism. Vintage Digital, Kindle Version, 2014.

GLOBAL CARBON PROJECT. Carbon budget 2018: an annual update of the global carbon budget and trends, 5 December 2018. Retrieved from: 〈www.globalcarbonproject.org/carbonbudget〉.

GLOBAL FOOTPRINT NETWORK. National Footprint Accounts, 2016. Retrieved from: 〈http://www. footprintnetwork.org/en/index.php/GFN/>.

GRIGGS, D.; STAFFORD-SMITH, M.; GAFFNEY, O.; ROCKSTRÖM, J.; ÖHMAN, M.C.; SHYAMSUNDAR, P.; SHYAMSUNDA,R.P.; STEFFEN, W.; GLASER, G.; KANIE, N.; NOBLE, I. Policy: Sustainable development goals for people and planet. Nature, v. 495, n. 7441, p. 305-307, 2013.

HANSEN, J.; SATO, M.; HEARTY, P.; RUEDY, R.; KELLEY, M.; MASSON-DELMOTTE, V.; RUSSELL, G.; TSELIOUDIS, G.; CAO, J.; RIGNOT, E.; VELICOGNA, I.; TORMEY, B.; DONOVAN, B.; KANDIANO, E.; VON SCHUCKMANN, K.; KHARECHA, P.; LEGRANDE, A. N.; BAUER, M.; LO, K. W. Ice melt, sea level rise and superstorms: evidence from paleoclimate data, climate modeling, and modern observations that $2^{\circ} \mathrm{C}$ global warming could be dangerous. Atmospheric Chemistry and Physics, n. 16, p. 3761-3812, 2016. Retrieved from: 〈http://www.atmos-chem-phys.net/16/3761/2016/ acp-16-3761-2016.pdf〉.

HELLIWELL, J.; LAYARD, R.; SACHS, J. (ed.). World happiness report. New York: The Earth Institute, Columbia University, 2012. Retrieved from: 〈http://www.earth.columbia.edu/sitefiles/file/ Sachs\%20Writing/2012/World\%20Happiness\%20Report.pdf .

HOFFMANN, U. Can green growth really work and what are the true (socio-) economics of climate change? Geneva: UNCTAD, 2015 (Discussion Paper, n. 222). Retrieved from: <http://unctad.org/ en/PublicationsLibrary/osgdp2015d4_en.pdf).

HUESEMANN, M.; HUESEMANN, J. Techno-fix: why technology won't save us or the environment. Original edition. Gabriola Island, BC, Canada: New Society Publishers, 2011.

HUNT, T. Is there enough lithium to maintain the growth of the lithium-ion battery market? Are we nearing peak lithium? Greentech Media, June 02, 2015. Retrieved from: 〈https://www. greentechmedia.com/articles/read/is-there-enough-lithium-to-maintain-the-growth-of-thelithium-ion-battery-m\#gs.|Gpbj3tlı.

IPCC. Summary for policymakers. Global warming of $1.5^{\circ} \mathrm{C}$. Geneva, Switzerland: World Meteorological Organization, 2018.

JACKSON, T. Prosperity without growth? The transition to a sustainable economy. Sustainable Development Commission, 2009. Retrieved from: «www.sdcommission.org.uk/.../prosperity_ without_growth_report.pdf .

KHARAS H.; K. HAMEL. A global tipping point: half the world is now middle class or wealthier. Brookings, September 27, 2018. Retrieved from: 〈https://www.brookings.edu/blog/futuredevelopment/2018/09/27/a-global-tipping-point-half-the-world-is-now-middle-class-orwealthier/>. Access in: 16 Nov. 2018.

KOCHHAR, R. A global middle class is more promise than reality: from 2001 to 2011, nearly 700 million step out of poverty, but most only barely. Global Research Attitudes. PEW Research Center, 
August 13, 2015. Retrieved from: 〈http://www.pewglobal.org/2015/07/08/a-global-middle-classis-more-promise-than-reality/>.

KUMI, E.; ARHIN, A.; YEBOAH, T. Can post-2015 sustainable development goals survive neoliberalism? A critical examination of the sustainable development-neoliberalism nexus in developing countries. Environment, Development and Sustainability, v. 16, n. 3, p. 539-554, June 2014.

LAURANCE, W. Is the global era of massive infrastructure projects coming to an end? Yale Environment 360, July 10, 2018. Retrieved from: 〈https://e360.yale.edu/features/is-the-globalera-of-massive-infrastructure-projects-coming-to-an-end).

MARQUES, L. O sintomático desprezo pela ciência. Folha de S. Paulo, Jan. 6, 2019. Retrieved from: 〈https://www1.folha.uol.com.br/ilustrissima/2019/01/negacao-da-ciencia-ganha-forcaem-nacionalismo-que-une-esquerda-e-direita.shtml>.

MARTINE, G. Global population, development aspirations and fallacies. N-IUSSP's Online News Magazine, February 5, 2018. Retrieved from: 〈http://www.niussp.org/article/global-populationdevelopment-aspirations-and-fallacies/〉.

MARTINE, G.; ALVES, J. E. Economy, society and environment in the 21st century: three pillars or trilemma of sustainability? Revista Brasileira de Estudos de População, v. 32, n. 3, p. 433-459, set./dez. 2015. Retrieved from: 〈http://www.scielo.br/pdf/rbepop/v32n3/en_0102-3098-rbepopS0102-3098201500000027P.pdf>.

MASOOD, E. How China is redrawing the map of world science. Nature, v. 569, p. 20-23, May 2019.

MCKINSEY. Winning the $\$ 30$ trillion decathlon: going for gold in emerging markets. Insights \& Publications, August 2012. Retrieved from: 〈http://www.mckinseyquarterly.com〉.

MDG ADVERTISING. 5 Global advertising trends every marketer should watch. MDG, July 10, 2018. Retrieved from: <https://www.mdgadvertising.com/marketing-insights/5-global-advertisingtrends-every-marketer-should-watch/>. Access in: November 28, 2018.

MONBIOT, G. Frightened by Donald Trump? You don't know the half of it. The Guardian, November 31, 2016.

MOSS, T. What next for the millennium development goals? Global Policy, v. 1, n. 2, p. 218-220, 2010.

NOAA - National Oceanic and Atmospheric Administration. Global Climate Report - Annual 2016, Jan. 2017. Retrieved from: 〈https://www.ncdc.noaa.gov/sotc/global/201613〉.

NOAA. Arctic report card: climate change effects go far beyond ice and polar bears. Fortune, December 11, 2018. Retrieved from: <http://fortune.com/2018/12/11/climate-change-globalwarming-noaa-arctic-report-card-2018/>.

OGDEN, T. Techno-optimists beware. Stanford Social Innovation Review. Summer, 2012. Retrieved from: 〈https://ssir.org/book_reviews/entry/techno_optimists_beware〉.

OLSSON, L.; HOURCARDE, J. C.; KÖLHER, J. Sustainable development in a globalized world. Journal of Environment \& Development, v. 23, n. 1, p. 3-14, 2014.

O’NEILL, D. W. et al. A good life for all within planetary boundaries. Nature Sustainability, v. 1, p. 88-95, February 2018.

OSTROM, E. A polycentric approach for coping with climate change. Washington, DC: World Bank, 2009 (World Bank Policy Research Working Paper, n. 5095). Retrieved from: 〈https://ssrn. com/abstract=1494833〉. 
OWEN, D. The efficiency dilemma. If our machines use less energy, will we just use them more? The New Yorker, December 12, 2010. Retrieved from: 〈https://www.newyorker.com/ magazine/2010/12/20/the-efficiency-dilemmas.

PEW RESEARCH CENTER. The politics of climate. October 4, 2016. Retrieved from: 〈http://www. pewinternet.org/2016/10/04/the-politics-of-climate/>.

POLIMENI, J. M.; GIAMPIETRO, M.; MAYUMI, K. The Jevons Paradox and the myth of resource efficiency improvements. London: Earthscan, 2008.

RIFKIN, J. The zero marginal cost society - The internet of things, the collaborative commons, and the eclipse of capitalism. London: Palgrave MacMillan, 2014.

ROCKSTRÖM J.; GAFFNEY, O.; ROGELJ, J.; MEINSHAUSEN, M.; NAKICENOVIC, N.; SCHELLNHUBER, H. J. Science, v. 355, n. 6331, p. 1269-1271, 24 Mar 2017.

ROCKSTRÖM, J.; STORDALEN, G. A.; HORTON, R. Acting in the Anthropocene: the EAT-Lancet Commission. The Lancet, v. 387 (10036), p. 2364-2365, June 2016. Retrieved from: 〈https://www. thelancet.com/journals/lancet/article/PIIS0140-6736(16)30681-X/fulltext>.

ROCKSTRÖM, J.; STEFFEN, W.; NOONE, K.; PERSSON, Å.; ILL CHAPIN, F. S.; LAMBIN, E.; LENTON, T. M.; SCHEFFER, M.; FOLKE, C.; SCHELLNHUBER, H.; NYKVIST, B.; DE WIT, C. A.; HUGHES, T.; VAN DER LEEUW, S.; RODHE, H.; SÖRLIN, S.; SNYDER, P. K.; COSTANZA, R.; SVEDIN, U.; FALKENMARK, M.; KARLBERG, L.; CORELL, R. W.; FABRY, V. J.; HANSEN, J.; WALKER, B.; LIVERMAN, D.; RICHARDSON, K.; CRUTZEN, P.; FOLEY, J. Planetary boundaries: exploring the safe operating space for humanity. Ecology and Society, v. 14, n. 2, 2009.

ROUBINI, N. The global consequences of a Sino-American cold war. Project Syndicate: The World's Opinion Page. May 20, 2019. Retrieved from: 〈https://www.project-syndicate.org/commentary/ united-states-china-cold-war-deglobalization-by-nouriel-roubini-2019-05〉.

SCIENCE ADVANCES, v. 2, n. 11, e1501923, Nov. 09, 2016.

STEFFEN, W.; RICHARDSON, K.; ROCKSTRÖM, J.; CORNELL, S. E.; FETZER, I.; BENNETT, E. M.; BIGGS, R.; CARPENTER, S. R.; DE VRIES, W.; DE WIT, C. A.; FOLKE, C.; GERTEN, D.; HEINKE, J.; MACE, G. M.; PERSSON, L. M.; RAMANATHAN, V.; REYERS, B.; SÖRLIN, S. Planetary boundaries: guiding human development on a changing planet. Science, v. 347, n. 6223, Feb. 13, 2015.

STEFFEN, W.; ROCKSTRÖM, J.; RICHARDSON, K.; LENTON, T. M.; FOLKE, C.; LIVERMAN, D.; SUMMERHAYES, C. P.; BARNOSKY, A. D.; CORNELL, S. E.; CRUCIFIX, M.; DONGES, J. F.; FETZER, I.; LADE, S. J.; SCHEFFER, M.; WINKELMANN, R.; SCHELLNHUBER, H. J. Trajectories of the Earth System in the Anthropocene. PNAS, v. 115, n. 33, p. 8252-8259, Aug. 14, 2018. Retrieved from: 〈http://www.pnas.org/content/early/2018/07/31/1810141115〉.

STIGLITZ, J. E. Globalization and its new discontents. Project Syndicate: The World's Opinion Page. August 5, 2016. Retrieved from: 〈https://www. project-syndicate.org/commentary/globalizationnew-discontents-by-joseph-e--stiglitz-2016-08>.

STIGLITZ, J. E. Globalization and its discontents. New York: W.W. Norton, 2002.

SVERDLIK, Y. Here's how much energy all US Data Centers Consume. Data Center Knowledge, June 27, 2016. Retrieved from: 〈http://www.datacenterknowledge.com/archives/2016/06/27/ heres-how-much-energy-all-us-data-centers-consume/s.

THAKUR, R. The United Nations in global governance: rebalancing organized multilateralism for current and future challenges. Global Governance. Retrieved from: 〈http://www.un.org/en/ga/ president/65/initiatives/GlobalGovernance/Thakur_GA_Thematic_Debate_on_UN_in_GG.pdf〉. 
THE 169 COMMANDMENTS: the proposed sustainable development goals would be worse than useless. The Economist, March 26, 2015. Retrieved from: «www.economist.com/news/ leaders/21647286-proposed-sustainable-development-goals-would-be-worse-useless-169commandments>.

TVEBERG, G. Eight pitfalls in evaluating green energy solutions. Our Finite World. Posted on November 18, 2014. Retrieved from: 〈http://ourfiniteworld.com/2014/11/18/eight-pitfalls-inevaluating-green-energy-solutions/>.

UCHECHUKWU, A.; LI, K.; SHEN, Y. Energy consumption in cloud computing data centers. International Journal of Cloud Computing and Services Science (IJ-CLOSER), v. 3, n. 3, p. 31-48, June 2014. ISSN: 2089-3337.

UNEP. Resource efficiency: potential and economic implications. A report of the International Resource Panel. Paris, 2017. Retrieved from: 〈http://www.resourcepanel.org/reports/resourceefficiency. United Nations Environment Programmè.

UNEP. Global material flows and resource productivity: assessment report for the UNEP International Resource. Paris: United Nations Environment Programme, 2016.

UNEP. INDCS signal unprecedented momentum for climate agreement in Paris, but achieving 2 degree objective contingent upon enhanced ambition in future years. Nov. 2015. Retrieved from: 〈unep.org/NewsCentre/default.spx?DocumentID=26854\&ArticleID=35542\&l=en〉.

UNEP. World remains on unsustainable track despite hundreds of internationally agreed goals and objectives. GEO5 Press Release, Rio de Janeiro, 6 June 2012.

USGCRP. Climate science special report: fourth national climate assessment, volume I. Washington, DC: U.S. Global Change Research Program, 2017. DOI: 10.7930/J0J964J6.

USGCRP. Impacts, risks, and adaptation in the United States: fourth national climate assessment, volume II. Washington, DC: U.S. Global Change Research Program, 2018. DOI: 10.7930/NCA4.2018.

VIKSTRÖM, H.; DAVIDSSON S.; HÖÖK, M. Lithium availability and future production outlooks. Applied Energy, v. 110, n. 10, p. 252-266, 2013.

WEISS, T.G.; THAKUR, R. Global Governance and the UN: an unfinished journey. Bloomington: Indiana University Press, 2010.

WILK, R. Without consumer culture, there is no environmental crisis. PERN Network, 2017. Retrieved from: 〈https://www.populationenvironmentresearch.org/pern_files/statements/ PERN_Cyberseminar2017_Wilk.pdf〉.

WILLETT, W. et al. Food in the Anthropocene: the EAT-Lancet Commission on healthy diets from sustainable food systems. Lancet, 2019 (published online Jan 16.). Retrieved from: 〈http://dx.doi. org/10.1016/S0140-6736(18)31788-4>.

WOLF, M. The long and painful journey to world disorder. Financial Times, January 5, 2017. Retrieved from: 〈https://www.ft.com/content/ef13e61a-ccec-11e6-b8ce-b9c03770f8b1〉.

WORLD BANK. The making of a riskier future: How our decisions are shaping future disaster risk. Washington, D.C. 2016a. Retrieved from: 〈https://www.gfdrr.org/sites/default/files/publication/ Riskier\%20Future.pdf>.

WORLD BANK. Shock waves: managing the impacts of climate change on poverty. Washington, D.C. 2016b. Retrieved from: 〈https://openknowledge.worldbank.org/bitstream/ handle $/ 10986 / 22787 / 9781464806735$. pdf? sequence=13\&isAllowed=y). 
WORLD RESOURCES INSTITUTE. Creating a sustainable food future: a menu of solutions to feed nearly 10 billion people by 2050. Synthesis Report, December 2018. Retrieved from: 〈https://wriorg.s3.amazonaws.com/s3fs-public/creating-sustainable-food-future_0.pdf?_ $\mathrm{ga}=2.189077036 .683194667 .1544092349-1718241769.1544092349$ ).

WORLDWATCH INSTITUTE. State of the world 2010: transforming cultures, from consumerism to sustainability. New York: The Worldwatch Institute, W. W. Norton, 2010.

\section{About the authors}

George Martine is a sociologist/demographer with a Ph.D from Brown University and M.A. from Fordham University. He is a former President of the Brazilian Population Association, Senior Fellow at the Harvard Center for Population and Development, Director of UNFPA's Technical Team for Latin America and the Caribbean and Director of the Institute for Society, Population and Nature, inter alia. He currently works as a consultant on issues of social development, population and environment.

José Eustáquio Diniz Alves is a sociologist with a Master's in Economics and Ph.D. in Demography from the Centro de Desenvolvimento e Planejamento Regional (CEDEPLAR) at the Universidade Federal de Minas Gerais (UFMG), and post-doctorate at Population Studies Center (Nepo/ Unicamp). Professor and researcher at the Federal University of Ouro Preto from 1987-2002, and at the National School of Statistics (ENCE) of the Brazilian Census Bureau (IBGE) from 20022019, holding a position of coordinator of the Graduate Department from 2005 to March 2009. Vice-president and treasurer of the Brazilian Population Association (ABEP) from 2005-2008 and treasurer of the Latin American Population Association (ALAP) from 2013-2014. Currently he is an independent consultant.

\section{Contact address}

George Martine

SHIS QI 19/6/20

71655-060 - Brasília-DF, Brazil

José Eustáquio Diniz Alves

Escola Nacional de Ciências Estatísticas

Rua André Cavalcanti, 106, sala 502, Bairro de Fátima

20231-050 - Rio de Janeiro-RJ, Brazil

\section{Resumen}

Desorden en la gobernanza global y el caos en el cambio climático

Los científicos advierten que la actividad humana en el Antropoceno está provocando la transgresión de varios límites planetarios. La ecuación población, medio ambiente y desarrollo ha quedado insoluble. Este artículo revisa la trayectoria del cambio climático y discute las limitaciones de los esfuerzos actuales para lidiar con él. Analiza también la actual crisis en la gobernanza global y el desencanto generalizado que despierta y reflexiona sobre los riesgos que ese embrollo político presenta para nuestro futuro ambiental. Las respuestas globales son 
ineficaces debido al deterioro del multilaterismo y a la promoción continua del crecimiento económico insostenible basado en el consumismo. El descontento con las consecuencias de la globalización ha desestabilizado la gobernanza nacional y, en el proceso, ha corroído aún más las perspectivas de una gobernanza global eficaz para enfrentar crisis sociales, políticas y ambientales simbióticas. La frustración con las consecuencias de la globalización proporciona a los populistas una plataforma para atraer electores con esquemas ingenuos que incluyen la negación del cambio climático. Al mismo tiempo, surge una nueva división de poder económico, político e científico en torno de la Iniciativa Belt and Road de China. Se discuten caminos potenciales y obstáculos para el multilaterismo en el intento de resolver eses dilemas. La fe ciega en la tecnología, el negacionismo y la omnipresencia de la cultura de consumo dificultan la escalada necesaria de esfuerzos multilaterales. Desafortunadamente, votantes, instituciones y políticas solo se ajustarán cuando la intensificación de los desastres climáticos provocar un cambio radical de mentalidad.

Palabras clave: Limites planetarios. Crises de gobernanza, Ideología del crecimiento. Globalismo versus populismo. Soluciones alternativas.

\section{Resumo}

\section{Desordem na governança global e o caos nas mudanças climáticas}

Os cientistas alertam para o fato de que a atividade humana no Antropoceno está provocando a transgressão de vários limites planetários. A equação população, meio ambiente e desenvolvimento ficou insolúvel. Este artigo revisa a trajetória das mudanças climáticas, discute as limitações dos esforços atuais para lidar com elas e analisa a atual crise na governança global, além de refletir sobre os riscos que esse imbróglio político apresenta para o nosso futuro ambiental. As respostas globais são ineficazes devido à deterioração do multilaterismo e à promoção generalizada do crescimento econômico insustentável baseado no consumismo. 0 descontentamento com as consequências da globalização desestabilizou a governança nacional e, no processo, corroeu ainda mais as perspectivas de uma governança global eficaz para enfrentar crises sociais, políticas e ambientais simbióticas. A frustração com a globalização está proporcionando aos populistas uma plataforma para atrair eleitores com esquemas ingênuos que incluem o negacionismo. Ao mesmo tempo, uma nova divisão do poder econômico, político e científico está surgindo com a Belt and Road Initiative da China. Discutem-se caminhos potenciais e obstáculos para o multilaterismo na tentativa de resolver esse dilema. A fé cega na tecnologia, o negacionismo e a difusão da cultura de consumo dificultam os esforços multilaterais contra as ameaças ambientais. Infelizmente, parece que eleitores, instituições e políticas só se ajustarão depois que a intensificação dos desastres climáticos forçar uma mudança radical de mentalidade.

Palavras-chave: Limites planetários. Crises de governança. Ideologia do crescimento. Globalismo versus populismo. Soluções alternativas. 